\title{
Lateral
}

Journal of the Cultural Studies Association

\section{Review of Policing Life and Death: Race, Violence, and Resistance in Puerto Rico by Marisol LeBrón (University of California Press)}

by Angel Rodriguez Rivera | Book Reviews, Issue 9.2 (Fall 2020)

\begin{abstract}
Using a multifaceted and transdisciplinary approach, Marisol Lebrón analyzes the development of punitive governance in Puerto Rico. Lebrón's approach pays particular attention to how capitalist colonial settings in Puerto Rico lead to the categorization of racialized, gendered, and classed populations as problematic subjects who then become the target of state violence as public policy. Intertwined with the state and its legitimacy, the book also looks at how these populations resist repressive policies and affect social relations of power on the island.
\end{abstract}

KEYWORDS colonial, police, police brutality, $\underline{\text { Puerto Rico, race, resistance, violence }}$

Policing Life and Death: Race, Violence and Resistance in Puerto Rico. By Marisol Lebrón. Oakland, California: California University Press, 2019, pp. 320. ISBN ISBN 9780520300170 (paperback). US List \$29.95.

Marisol LeBrón's Policing Life and Death: Race, Violence, and Resistance in Puerto Rico is an examination of the relation between the intersectionality of race, poverty, gender, and the state in managing the "crime problem" in the colonial setting of Puerto Rico. The book describes how punitive measures established by the government of Puerto Rico are confronted with resistance from targeted populations labeled as criminal, 1 creating an interesting play of power relations on the island. As an unintended consequence, the book is a great account of how the state in a postindustrial, post-Fordist ${ }^{2}$ setting loses legitimacy and struggles_-through repressive and punitive measures-to maintain power and control over subaltern populations.

The point of departure for the book is the establishment of "punitive governance" as public policy during the early part of the 1990s in Puerto Rico. Punitive governance refers to "ways in which the Puerto Rican state has reasserted itself in the lives of Puerto Ricans through technologies of punishment such as policing, incarceration, as well as the violence (state sanctioned or other) they often provoke" (13). The book argues that this policy is the result of an unequal distribution of life chances and resources on the island.

Punitive governance in Puerto Rico develops as part of the ongoing colonization process led by "technocrats and colonial elites." This process defines and labels criminal populations as those that occupy the societal margins. Instead of a monolithic view of the margins, LeBrón argues that these surplus populations are diversely racialized, gendered, 
and classed. The intersectionality of these social elements creates different forms of resistance to the colonial state apparatus and the colonial capitalist relations that it entails.

LeBrón's background in "Latinx studies, Black studies, carceral studies, feminist studies, queer studies, and critical ethnic studies" (18) serves to address the complex relations of oppression and exploitation within Puerto Rico. Furthermore, LeBrón investigates the highly secretive and prejudiced institution of the Puerto Rico Police Department, making her work a political statement in and of itself.

Policing Life and Death uses a transdisciplinary approach to understanding the processes through which Puerto Ricans negotiate power relations within the context of an ongoing political end economic crisis. The process relates to both the hegemonic powers personified in state institutions like the Puerto Rico Police Department and social groups that resist punitive governance. This demands a very sophisticated approach to gathering information. LeBrón uses media accounts of different events, cultural texts, government documents, and in depth interviews with both state agents and racialized, gendered, and classed actors who participate in resistance processes on the island.

The book begins with an in-depth historical analysis and explanation of how Puerto Rico has developed as a colony of the United States. The ongoing colonial history of the island serves as the underlining condition that permeates the rest of the book, the condition that led to the formation of current social groups and conditions on the island. In chapter one, LeBrón shows how the colonial state in Puerto Rico and its "mano dura" policies defined racialized communities as surplus populations-and as deserving of the proliferation of violence against and within these communities. The second chapter discusses how the colonial elites on the island moved from a Cold War model focused on the island's strategic importance, to a new strategy of punitive governance. This new strategy became a resignification of the importance of Puerto Rico as a colony.

In chapters three and four, LeBrón develops the topic of how criminalization evolved in the island, formed through race, gender and class, and the state's response to it. Chapter three presents an understanding of how processes of racialization and gendering relate to the criminalization of cultural patterns in Puerto Rico. For example, the definition of certain musical forms as criminal becomes an ideological tool of a material repressive policy. Chapter four deals with how the early 1990s punitive governance policy became the paradigm for understanding crime, violence, and the state's "war" against them. Chapter five's main example is the way in which state violence against protesters was framed in same manner as violence against poor communities on the island. In the process, punitive governance policies allowed the state to maintain control over protests that question the state's legitimacy.

Chapters six and seven move to other ways that Puerto Ricans, both on the island and in the diaspora, have resisted punitive and repressive policies targeting certain populations in Puerto Rico. The process of resisting has used social media as well as community organizing strategies. The final chapter establishes how punitive governance has been a strategy based on prejudice and the labeling of disadvantaged populations on the island on the basis of class, race, and gender.

Policing Life and Death does a great job of looking at the intricacies of capitalist colonial responses to the "crime problem" in Puerto Rico. It intertwines a variety of social variables in the relations of power that shape these policies and the processes that resist them. It is 
methodologically rigorous and theoretically sophisticated. Its analysis goes beyond the obvious and pays attention to a multifaceted set of criteria. A great development of this work could be a more in-depth analysis of how race and racial relations are formed and conceived on the island. Racialized populations and racialized social relations are constant topics in this book, however, a further exploration of racial definitions and how they are developed, defined, and redefined and its connection with crime and criminalization in Puerto Rico would be an important contribution to the rising scholarship of race and racism in Puerto Rico.

Policing Life and Death: Race, Violence, and Resistance in Puerto Rico is an excellent analysis of the colonial state response to "crime." In particular, the book's framing of the issues, its solid research methodology, and diversity of approaches to the analysis of crime, policy responses, and resistances, makes for a great critique of the legitimacy and role of the state in contemporary social relations.

\section{Notes}

1. Joel Villa-Rodríguez and Gary Gutiérrez-Renta, Criminología Crítica y Aplicada (San Juan: Create Space Independent Publishing Platform, 2013).

2. Angel Rodríguez-Rivera, "Acumulación, Estado, y Sociedad Civil: Mitos y Contradicciones de un Nuevo Contrato Social" in Rodríguez-Ramos. (ed.) La Invariable Crisis (San Juan: Publicaciones Gaviota, 2020): 55-74.

\section{Author Information}

\section{Angel Rodriguez Rivera}

Angel Rodriguez-Rivera is an Associate Professor at the University of Puerto Rico-Cayey. He has a MSW in community social work from the University of Puerto Rico-Rio Piedras Campus. Also has a PhD in Sociology from Purdue University in Indiana, with a specialty in political economy. His areas of academic interests are varied. He has done research in the state formation process in postcolonial setting. He has also done research about race and racial relations in Puerto Rico. He has particular interests in the process of acting race and the racial categories that arise out that process. Dr. Rodriguez also researches popular music in Puerto Rico and how it reflects processes of exploitation and resistance in a post-Fordist stage of capitalism. Recently, he has been researching social movements and their relations to mass media.

View all of Angel Rodriguez Rivera's articles.

\section{Article details}

Angel Rodriguez Rivera, "Review of 'Policing Life and Death: Race, Violence, and Resistance in Puerto 
Rico' by Marisol LeBrón (University of California Press)," Lateral 9.2 (2020).

https://doi.org/10.25158/L9.2.13

This content is licensed under a Creative Commons Attribution-NonCommercial 4.0 International License. Copyright is retained by authors.

Lateral is the peer-reviewed, open access journal of the Cultural Studies Association.

ISSN 2469-4053 